\title{
ПРОБЛЕМЫ РЕАЛИЗАЦИИ ПОЛНОМОЧИЙ УПРАВЛЕНИЯ ФЕДЕРАЛЬНОЙ СЛУЖБЫ ПО ВЕТЕРИНАРНОМУ И ФИТОСАНИТАРНОМУ НАДЗОРУ ПО САНКТ-ПЕТЕРБУРГУ, ЛЕНИНГРАДСКОЙ И ПСКОВСКОЙ ОБЛАСТЯМ И ПУТИ ИХ РЕШЕНИЯ
}

\author{
(C) 2020 Кудрявцева Татьяна Юрьевна
}

заместитель директора по научной деятельности, Высшая инженерно-экономическая школа Санкт-Петербургский политехнический университет Петра Великого, Россия, Санкт-Петербург

E-mail: kudryavtseva_tyu@spbstu.ru

\section{(c) 2020 Текутов Павел Александрович}

соискатель, Высшая инженерно-экономическая школа

Санкт-Петербургский политехнический университет Петра Великого, Россия, Санкт-Петербург

Объектом исследования в статье является территориальное управление Федеральной службы по ветеринарному и фитосанитарному надзору по Санкт-Петербургу, Ленинградской и Псковской областям (далее - Управление Россельхознадзора) - государственный орган, находящийся в подчинении Россельхознадзора. В качестве основных проблем реализации функций органа контрольнонадзорной деятельности были выделены следующие:

- пересечение полномочий контрольно-надзорных органов;

- отсутствие регламентации и стандартизации процессов осуществления контрольных мероприятий;

- недостаточный уровень регламентации взаимодействия с органами прокуратуры;

- несовершенство контрольно-надзорных процедур;

- недостаточный размер штрафов/налогов;

- отсутствие электронной фитосанитарной сертификации;

- несовершенство имеющихся информационных систем Россельхознадзора;

- неоднозначность показателей эффективности использования бюджетных средств.

В качестве путей решения указанных проблем выделены следующие основные направления:

- правовое: принятие административного регламента взаимодействия федеральных органов государственной власти; правовое закрепление механизмов регулирования отношений в сфере производства и обращения зерна и продуктов его переработки; закрепление в нормативно-правовых актах легитимности электронной фитосанитарной сертификации;

- методологическое: разработка методов государственного регулирования в сфере производства и обращения зерна и продуктов его переработки; разработка более эффективного алгоритма изъятия земель;

- информационное: внедрение электронной фитосанитарной сертификации в автоматизированной программе «Аргус Фито»; увеличение производительности систем; развитие системы поддержки пользователей.

Ключевые слова: управление Федеральной службы по ветеринарному и фитосанитарному надзору, Управление Россельхознадзора, функции органа контрольно-надзорной деятельности, эффективность деятельности, бюджетные ассигнования.

Федеральная служба по ветеринарному и фитосанитарному надзору (далее - Россельхознадзор) является федеральным органом исполнительной власти, осуществляющим функции по контролю и надзору в сфере ветеринарии, карантина и защиты растений, безопасного обращения с пестицидами и агрохимикатами, обе- спечения плодородия почв, обеспечения качества и безопасности зерна, крупы, комбикормов и компонентов для их производства, побочных продуктов переработки зерна, земельных отношений (в части, касающейся земель сельскохозяйственного назначения, оборот которых регулируется Федеральным законом «Об обороте 
земель сельскохозяйственного назначения» [1]), обращения лекарственных средств для ветеринарного применения, карантина и защиты растений, функции по защите населения от болезней, общих для человека и животных [2].

Россельхознадзор находится в ведении Министерства сельского хозяйства Российской Федерации. Россельхознадзор осуществляет свою деятельность непосредственно и через свои территориальные органы с привлечением уполномоченных и подведомственных ей организаций, которые аккредитованы и имеют лицензии в установленной сфере деятельности.

Россельхознадзор осуществляет следующие полномочия в установленной сфере деятельности [2]:

- ветеринарный контроль в пунктах пропуска через Государственную границу Российской Федерации, контроль за соблюдением требований технических регламентов;

- контроль безопасности кормов, изготовленных с применением технологий генной инженерии;

- контроль безопасности обращения с пестицидами и агрохимикатам;

- земельный надзор в отношении земель сельскохозяйственного назначения;

- карантинный фитосанитарный контроль;

- надзор в сфере обращения лекарственных средств для ветеринарного применения;

- контроль качества и безопасности зерна, крупы, комбикормов и компонентов для их производства, продуктов переработки зерна;

- выдача разрешений на ввоз в Российскую Федерацию и вывоз из Российской Федерации, а также на транзит по ее территории животных, продукции животного происхождения, лекарственных средств для ветеринарного применения, кормов и кормовых добавок для животных;

- выдача фитосанитарных сертификатов, реэкспортных фитосанитарных сертификатов и карантинных сертификатов;

- выдача лицензий на осуществление фармацевтической деятельности в сфере обращения лекарственных средств для ветеринарного применения.

Россельхознадзор осуществляет функции главного распорядителя и получателя средств федерального бюджета, предусмотренных на содержание Службы и реализацию возложенных на Службу функций.

Объектом исследования является террито- риальное управление Федеральной службы по ветеринарному и фитосанитарному надзору по Санкт-Петербургу, Ленинградской и Псковской областям (далее - Управление Россельхознадзора) - государственный орган, находящийся в подчинении Россельхознадзора.

Эффективность деятельности Управления Россельхознадзора в значительной степени зависит от эффективности расходования бюджетных средств, расходуемых на удовлетворение потребностей Управления, их материальнотехническое обеспечение. Федеральная служба по ветеринарному и фитосанитарному надзору как субъект бюджетного планирования является уполномоченным федеральным органом исполнительной власти.

Задачи в области повышения эффективности и результативности бюджетных ассигнований на сегодняшний день сводятся к усилению бюджетного планирования с учетом приоритетов государственной политики и общественной значимости конечных результатов использования финансовых ресурсов. Переориентация деятельности органов власти и администраторов бюджетных средств с «освоения» выделенных им ассигнований на достижение конечных, общественно значимых и измеряемых результатов предполагает применение принципиально новой идеологии бюджетного планирования, ориентированного на результат.

Реализация стратегической цели и тактических задач, стоящих перед Россельхознадзором, осуществляется в рамках федеральных и ведомственных целевых программ. Программная деятельность предполагает четкое разделение и оптимальное сочетание федеральных целевых программ как инструмента экономической политики государства и ведомственных целевых программ как инструмента бюджетного планирования, направленное на решение тактических задач. Сбалансированность программных мероприятий направлена на обеспечение укрепления финансовой дисциплины, повышение прозрачности использования бюджетных средств, снижение управленческих расходов.

Финансирование Россельхознадзора осуществляется на основании Государственной программы развития сельского хозяйства и регулирования рынков сельскохозяйственной продукции, сырья и продовольствия [3] (утверждена Постановлением Правительства от 14.07.2012 № 717) и ведомственной целевой программы 
«Организация ветеринарного и фитосанитарного надзора» [4].

Исходя из данных представленных в данной программе автором произведено сопоставление задач программы с индикаторами их достижения в таблице 1.

Ежегодно Управлением Россельхознадзора по Санкт-Петербургу, Ленинградской и Псковской областям формируется проект бюджетной сметы на плановый период. Планирование расходов осуществляется с учетом бюджетной классификации в соответствии с требованиями Министерства финансов. Для определения бюджетных ассигнований на плановый период используются следующие методы расчета: нормативный метод, метод индексации, плановый и программно-целевой методы (таблица 2). Также стоит отметить, что планирование бюджетных ассигнований на плановый период допустимо только в пределах доведенных предельных объемов бюджетных ассигнований по укрупненным КОсГУ бюджетной классификации.

При планировании бюджетных ассигнований, выделяемых на материально-техническое обеспечение, преимущественно используется нормативный метод. Важно отметить, что Управлением при планировании бюджетных ассигнований не используется программноцелевой метод бюджетного планирования.

Рассмотрим объем бюджетных ассигнований, выделенный на финансирование Управления Россельхознадзора по Санкт-Петербургу, Ленинградской и Псковской областей за период с 2016-2019 гг. см. таблицу 3.

Таблица 1. Задачи и индикаторы задач целевой программы

\begin{tabular}{|c|c|}
\hline Задачи программы & Индикаторы задач \\
\hline $\begin{array}{l}\text { Предупреждение обращения на территории Россий- } \\
\text { ской Федерации небезопасных и некачественных в } \\
\text { ветеринарно-санитарном отношении товаров }\end{array}$ & $\begin{array}{l}\text { Охват исследованиями объектов, находящихся на } \\
\text { территории Российской Федерации и занятых оборо- } \\
\text { том товаров (\%) }\end{array}$ \\
\hline $\begin{array}{l}\text { Предупреждение обращения на территории россий- } \\
\text { ской Федерации некачественных лекарственных } \\
\text { средств для ветеринарного применения }\end{array}$ & $\begin{array}{l}\text { Доля исследованных в рамках проведения контроля } \\
\text { качества лекарственных средств для ветеринарного } \\
\text { применения от общего количества наименований } \\
\text { лекарственных средств для ветеринарного приме- } \\
\text { нения, находящихся в обращении на территории } \\
\text { Российской Федерации (\%) }\end{array}$ \\
\hline $\begin{array}{l}\text { Недопущение ввоза из иностранных государств не- } \\
\text { безопасных в ветеринарно-санитарном отношении } \\
\text { товаров }\end{array}$ & $\begin{array}{l}\text { Доля не допущенных к ввозу из иностранных госу- } \\
\text { дарств подлежащих ветеринарному контролю това- } \\
\text { ров, не соответствующих требованиям Евразийского } \\
\text { экономического союза и Российской Федерации (\%) }\end{array}$ \\
\hline $\begin{array}{l}\text { Улучшение (сохранение) фитосанитарного состояния } \\
\text { территории Российской Федерации }\end{array}$ & $\begin{array}{l}\text { Доля площади упраздненных карантинных фитоса- } \\
\text { нитарных зон в общей площади земель сельскохо- } \\
\text { зяйственного назначения (\%); }\end{array}$ \\
\hline $\begin{array}{l}\text { Недопущение ввоза из иностранных государств } \\
\text { генно-инженерно-модифицированных семян }\end{array}$ & $\begin{array}{l}\text { Доля запрещенных к ввозу из иностранных госу- } \\
\text { дарств генно-инженерно-модифицированных семян } \\
\text { (\%) }\end{array}$ \\
\hline $\begin{array}{l}\text { Недопущение обращения на территории Российской } \\
\text { Федерации небезопасных и некачественных семян } \\
\text { сельскохозяйственных растений }\end{array}$ & $\begin{array}{l}\text { Охват исследованиями поднадзорных государствен- } \\
\text { ному надзору в области в области семеноводства } \\
\text { семян, от общей потребности Российской Федерации } \\
\text { в семенном материале (\%) }\end{array}$ \\
\hline $\begin{array}{l}\text { Недопущение обращения на территории Российской } \\
\text { Федерации небезопасного зерна и продуктов его } \\
\text { переработки }\end{array}$ & $\begin{array}{l}\text { Доля не допущенного в обращение на территории } \\
\text { Российской Федерации небезопасного зерна и про- } \\
\text { дуктов его переработки (\%) }\end{array}$ \\
\hline $\begin{array}{l}\text { Предотвращение (снижение) выбытия из сельскохо- } \\
\text { зяйственного оборота земель сельскохозяйственного } \\
\text { назначения }\end{array}$ & $\begin{array}{l}\text { Предотвращение выбытия из оборота сельскохозяй- } \\
\text { ственных земель (\%) }\end{array}$ \\
\hline $\begin{array}{l}\text { Развитие информационных систем Россельхознад- } \\
\text { зора }\end{array}$ & $\begin{array}{l}\text { Доступность информационных систем Россельхоз- } \\
\text { надзора (\%) }\end{array}$ \\
\hline $\begin{array}{l}\text { Проведение необходимого количества исследований } \\
\text { в целях обеспечения ветеринарной и фитосанитар- } \\
\text { ной безопасности Российской Федерации }\end{array}$ & $\begin{array}{l}\text { Уровень выполнения подведомственными учрежде- } \\
\text { ниями государственных услуг и работ по направле- } \\
\text { ниям реализации ведомственной целевой програм- } \\
\text { мы (\%) }\end{array}$ \\
\hline $\begin{array}{l}\text { Снижение распространения заразных болезней жи- } \\
\text { вотных путем строительства/реконструкции лабора- } \\
\text { торий }\end{array}$ & $\begin{array}{l}\text { Количество введенных объектов капитального стро- } \\
\text { ительства (ед.) }\end{array}$ \\
\hline
\end{tabular}


Таблица 2. Методы планирования бюджетных ассигнований Управления Россельхознадзора

\begin{tabular}{|l|l|}
\hline Наименование метода & \multicolumn{1}{|c|}{ Описание метода } \\
\hline Нормативный метод & $\begin{array}{l}\text { Бюджетные ассигнования рассчитываются в соответствии с нормативами, уста- } \\
\text { новленными соответствующими нормативными актами. Таким нормативным до- } \\
\text { кументом является Приказ Россельхознадзора от 09.10.2015 № 686 «Об утвержде- } \\
\text { нии нормативных затрат на обеспечение функий территориальных управлений } \\
\text { Россельхознадзора» [5]. Данный документ устанавливает нормы по количестве и } \\
\text { цене для всех групп товаров, работ, услуг. }\end{array}$ \\
\hline Метод индексации & $\begin{array}{l}\text { Данный метод используется для проведения индексации фонда оплаты труда на } \\
\text { плановый период (индекс устанавливается Министерством финансов), а также } \\
\text { предельного уровня цен товаров, работ, услуг (индексы рассчитываются Россель- } \\
\text { хознадзором в централизованном порядке одновременно для всех территориаль- } \\
\text { ных управлений) }\end{array}$ \\
\hline
\end{tabular}

Таблица 3. Бюджетные ассигнования Управления Россельхознадзора по Санкт-Петербургу, Ленинградской и псковской областях с 2016 по 2019 годы

\begin{tabular}{|l|c|c|c|c|}
\hline \multicolumn{1}{|c|}{ Виды бюджетных ассигнований } & $\begin{array}{c}2016 \\
\text { (тыс.руб.) }\end{array}$ & $\begin{array}{c}2017 \\
\text { (тыс.руб.) }\end{array}$ & $\begin{array}{c}2018 \\
\text { (тыс.руб.) }\end{array}$ & $\begin{array}{c}2019 \\
\text { (тыс.руб.) }\end{array}$ \\
\hline Фонд оплаты труда (с налогами) & 220659,57 & 240830,41 & 343620,58 & 454549,92 \\
\hline $\begin{array}{l}\text { Целевая субсидия на обеспечение } \\
\text { территориальных управлений } \\
\text { бланками строгой отчетности }\end{array}$ & 36000,00 & 36000,00 & 36000,00 & 36000,00 \\
\hline Повышение квалификации & 258,92 & 248,92 & 90,57 & 987,92 \\
\hline Капитальный ремонт & 18000,00 & - & - & - \\
\hline Остальные закупки & 67166,36 & 74242,35 & 74676,37 & 71595,72 \\
\hline ИтОГО: & 342084,85 & 351321,68 & 454387,52 & 564133,56 \\
\hline
\end{tabular}

Анализ доведенных бюджетных ассигнований за период с 2016 по 2019 годы показывает скачок в доведении фонда оплаты труда 2017 года по сравнению с 2018 годом. Данная разница объясняется передачей полномочий с 01.11.2017 по субъекту Псковская область от Управления Россельхознадзора по Тверской и Псковской областям, Управлению Россельхознадзора по Санкт-Петербургу и Ленинградской области.

Также следует отметить, что в соответствии с Приказом Россельхознадзора от 25.01.2017 № 51 [6] Управление Россельхознадзора по СанктПетербургу, Ленинградской и Псковской областям наделено полномочиями по планированию и осуществлению централизованных закупок на оказание услуг по изготовлению бланков строгой отчетности для всех территориальных управлений Россельхознадзора. В рамках данного приказа Управление получает целевую субсидию в размере 36 млн. руб. ежегодно.

Таким образом, в связи с отсутствием действенных методик оценки эффективности произведенных затрат, возникают вопросы нецелевого и неэффективного использования бюджетных средств. Кроме того, бюджетные расходы не взаимоувязаны с основными зада- чами и индикаторами задач ведомственной целевой программы. Необходимо разработать инструменты, позволяющие производить оценку эффективности расходов федерального бюджета на содержание Управления Россельхознадзора.

Важнейшим направлением реформирования бюджетного процесса в настоящее время является повышение эффективности и результативности бюджетных расходов [7]. Этот факт предопределяет направления совершенствования системы оценки эффективности деятельности государственных органов, оценки эффективности расходования бюджетных средств.

Рассмотрим проблемы реализации функций Управления Россельхознадзора по СанктПетербургу, Ленинградской и Псковской областям исходя из поставленных перед ним задач.

Задача 1. Предотвращение (снижение) выбытия из сельскохозяйственного оборота земель сельскохозяйственного назначения.

Государственный земельный надзор является важным звеном в системе государственного управления земельными ресурсами, одной из основных мер обеспечения рационального использования и охраны земель, защиты земельных прав граждан, юридических лиц. 
В последнее время сохраняются проблемы осуществления надзорной функции управления земельными ресурсами, в том числе касающиеся реализации надзорными органами полномочий, относящихся к их компетенции. Эти проблемы во многом обусловлены множественностью надзорных федеральных органов исполнительной власти в области земельных отношении (рисунок 1).

Несмотря на то, что надзорные полномочия этих органов определены Положением о государственном земельном надзоре, утвержденным постановлением Правительства РФ от 2 января 2015 г. № 15 [8], возникают вопросы разграничения между ними полномочий. Например, целевое назначение использования земельных участков может проверить как Россельхознадзор, так и Росреестр, что ведет к увеличению нагрузки на бизнес, а также к неэффективному использованию бюджетных средств (увеличение затрат на организацию проверок, транспортные расходы и т.д.).

Подобные ситуации вызывают необходимость определения взаимодействия, осуществления координации и согласования деятельности федеральных надзорных органов в земельной сфере. Для этого необходимо принятие административного регламента взаимодействия федеральных органов государственной власти, осуществляющих государственный зе- мельный надзор [9].

Еще одной проблемой осуществления государственного земельного надзора является несовершенство имеющейся нормативно-правовой базы. Основной целью государственного земельного надзора является вовлечение земель в сельскохозяйственный оборот. Этой цели препятствуют следующие факторы: длительность процедур, требующихся для вовлечения неиспользуемых земель в оборот, в том числе, путем изъятия земельных участков у собственников, которые не используют их по назначению, а также оформления невостребованных долей; неэффективность действующих мер государственного принуждения к использованию земли в целях сельскохозяйственного производства, в частности, незначительный размер штрафов и отсутствие повышенных ставок земельного налога за неиспользование таких земель.

Задача 2. Предупреждение обращения на территории Российской Федерации небезопасных и некачественных в ветеринарно-санитарном отношении товаров/ лекарственных средств.

В соответствии с постановлением Правительства Российской Федерации от 05.06.2013 № 476 [10] Управление осуществляет государственный ветеринарный надзор:

- в отношении органов государственной власти, органов местного самоуправления, юридических лиц и индивидуальных предпринима-

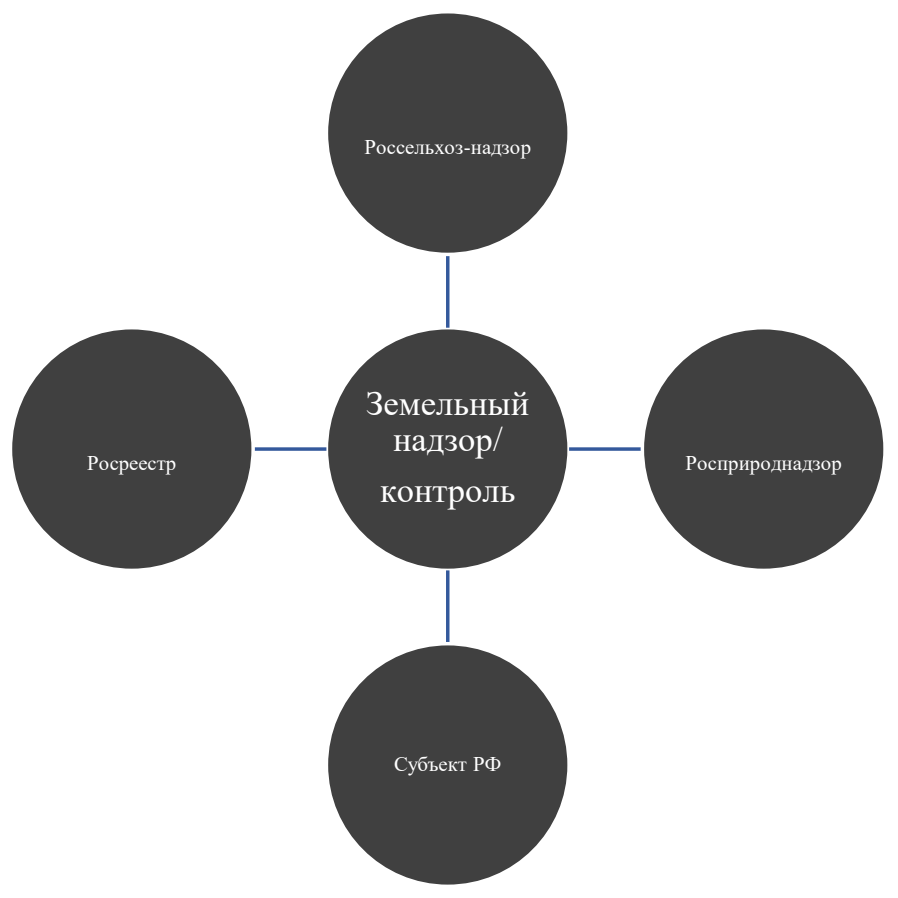

Рисунок 1. Органы власти, осуществляющие полномочия в сфере земельного надзора/контроля 
телей, осуществляющих транзит товаров, подлежащих ветеринарному контролю (надзору);

- контроль за ветеринарно-санитарными правилами перевозки, перегона или убоя животных либо правил заготовки, переработки, хранения или реализации продуктов животноводства;

- контроль качества лекарственных средств для ветеринарного применения.

При реализации надзорных и ограничительных мероприятий по предупреждению распространения заразных болезней животных часто возникает необходимость в их незамедлительном осуществлении. Действующий алгоритм согласования таких проверок, осуществляемый органами прокуратуры субъектов Российской Федерации, не обеспечивает срочности принятия решения о проведении внеплановой проверки [11].

Также органы прокуратуры часто отказывают в согласовании проведения внеплановой проверки, что, как следствие, может привести к возникновению/распространению особо опасных болезней животных и нанести значительный экономический ущерб хозяйствующим субъектам.

Также необходимо отметить наличие пересечения полномочий с органами регионального ветеринарного надзора. Одни и те же хозяйствующие субъекты входят в планы проверок как Управления Россельхознадзора по Санкт-Петербургу, Ленинградской и Псковской областях, так и Управления ветеринарии Санкт-Петербурга. Это в свою очередь создает дополнительные административные барьеры для осуществления деятельности хозяйствующими субъектами и препятствует выходу на рынок новых участников рынка. Дублирующие проверочные мероприятия ведут к неэффективному расходованию бюджетных средств. Одни и те же проверки финансируются из федерального бюджета (проводимые Россельхознадзором) и из местного бюджета (Управление ветеринарии). В рамках проведения ветеринарного надзора необходима централизация полномочий на федеральном уровне.

Задача 3. Улучшение (сохранение) фитосанитарного состояния территории Российской Федерации.

Государственный карантинный фитосанитарный контроль (надзор) в Российской Федерации направлен на обеспечение охраны растений и территории Российской Федерации от проникновения на нее и распространения по ней карантинных объектов, предотвращение ущерба от распространения карантинных объектов, соблюдение карантинных фитосанитарных требований стран-импортеров и осуществляется федеральным органом исполнительной власти, осуществляющим функции по контролю и надзору в области карантина растений. В соответствии с Федеральным законом от 21.07.2014 № 206-Ф3 «О карантине растений» [12] государственный карантинный фитосанитарный контроль (надзор) осуществляется:

1) в пунктах пропуска через Государственную границу Российской Федерации за подкарантинной продукцией, ввозимой в Российскую Федерацию из иностранных государств, в том числе перемещаемой в почтовых отправлениях, в ручной клади и багаже пассажиров, членов экипажей морских судов, речных судов, воздушных судов, транспортных средств, поездных бригад, за транспортными средствами, которыми осуществляется ввоз в Российскую Федерацию подкарантинной продукции;

2) в иных местах, в которых в соответствии с законодательством Российской Федерации оборудованы пункты карантина растений, перечень которых утверждается федеральным органом исполнительной власти, осуществляющим функции по контролю и надзору в области карантина растений, за подкарантинной продукцией при ее обороте на территории Российской Федерации;

3) в местах хранения и переработки подкарантинной продукции за подкарантинными объектами;

4) за выполнением гражданами, юридическими лицами работ, связанных с подкарантинной продукцией или подкарантинными объектами.

Одним из основных индикаторов достижения данной задачи является доля площади упраздненных карантинных фитосанитарных зон. В связи с отменой Приказа Министерства сельского хозяйства от 13.02.2008 № 43 «Об установлении и упразднении карантинной фитосанитарной зоны, установлении и отмене карантинного фитосанитарного режима, о наложении и снятии карантина» [13] отсутствует алгоритм действий по снятию карантинных фитосанитарных зон с хозяйствующих субъектов.

Наличие карантинной фитосанитарной зоны на территории хозяйствующего субъекта 
ведет к дополнительным расходам собственников бизнеса на проведение лабораторных испытаний при вывозе продукции с территории объекта, что в свою очередь приводит к увеличению стоимости продукции для потребителей.

Другой проблемной точкой в деятельности фитосанитарного контроля является отсутствие электронной фитосанитарной сертификации. Фитосанитарный сертификат - это документ международного образца, свидетельствующий, что ввозимая или вывозимая продукция растительного происхождения соответствует всем карантинным фитосанитарным требованиям страны назначения.

Внедрение электронной фитосанитарной сертификации позволило бы сократить количество времени на осуществление контрольнонадзорных действий при проходе подконтрольных грузов через Государственную границу Российской Федерации. Кроме того, в совокупности с полным переходом на электронную сертификацию отпадет необходимость в размещении централизованных закупок на оказание услуг по изготовление бланков строгой отчетности, что приведет к экономии бюджетных средств в размере 36 млн. руб. ежегодно.

Задача 4. Недопущение обращения на территории Российской Федерации небезопасных и некачественных семян сельскохозяйственных растений.

По состоянию на сегодняшний день данную задачу Управлению Россельхознадзора трудно реализовать ввиду низких штрафов, предусмотренных Кодексом Российской Федерации об административных правонарушениях. Статьей 10.12 данного Кодекса нарушение правил производства, заготовки, обработки, хранения, peализации, транспортировки и использования семян сельскохозяйственных растений [14] влечет предупреждение или наложение административного штрафа на граждан в размере от трехсот до пятисот рублей; на должностных лиц - от пятисот до одной тысячи рублей; на юридических лиц - от пяти тысяч до десяти тысяч рублей. Такой размер штрафов привлекает недобросовестных участников бизнеса.

В результате в обороте семян сельскохозяйственных растений все чаще выявляются просроченные или засоренные семена, не кондиция и пересортица (когда один сорт продается под видом другого), а то и опасные сорняки, занос которых может неблагоприятно отразится на сельском хозяйстве региона.

Задача 5. Недопущение обращения на территории Российской Федерации небезопасного зерна и продуктов его переработки.

Данная задача также является трудно достижимой ввиду того, что в Российской Федерации отсутствует закон о зерне. Соответственно отсутствуют правовые основы осуществления государственного контроля и надзора за качеством зерна и продуктов его переработки при их ввозе (вывозе) на территорию страны, закладке в государственный резерв и закупке для государственных нужд. Это создает предпосылки бесконтрольного ввоза на территорию России заведомо некачественной продукции, занижения характеристик зерна при его приобретении у сельхозпроизводителей, произвольных изменений его характеристик при последующем обороте и, как следствие, репутационных потерь страны.

Необходимо издание федерального закона в рамках которого необходимо предусмотреть: правовые механизмы регулирования отношений в сфере производства и обращения зерна и продуктов его переработки; методы государственного регулирования в сфере производства и обращения зерна и продуктов его переработки; правовые основы функционирования системы государственного контроля (надзора) в области обеспечения качества и безопасности при производстве и обращении зерна и продуктов его переработки; обеспечение количественнокачественного учёта зерна и продуктов его переработки в Российской Федерации.

Задача 6. Развитие информационных систем Россельхознадзора.

Для эффективной деятельности контрольнонадзорному органу необходима качественная, полная, достоверная и своевременная информация о реальном состоянии или действии контролируемых объектов.

K информационным системам Россельхознадзора относятся следующие автоматизированные системы: государственная информационная система в области ветеринарии ВетИС, Аргус-Фито (оформление и учет документов фитосанитарного надзора, рассмотрения заявок на ввоз, вывоз или транзит продукции растительного происхождения). Схема интеграции данных систем представлена на рисунке 2. 


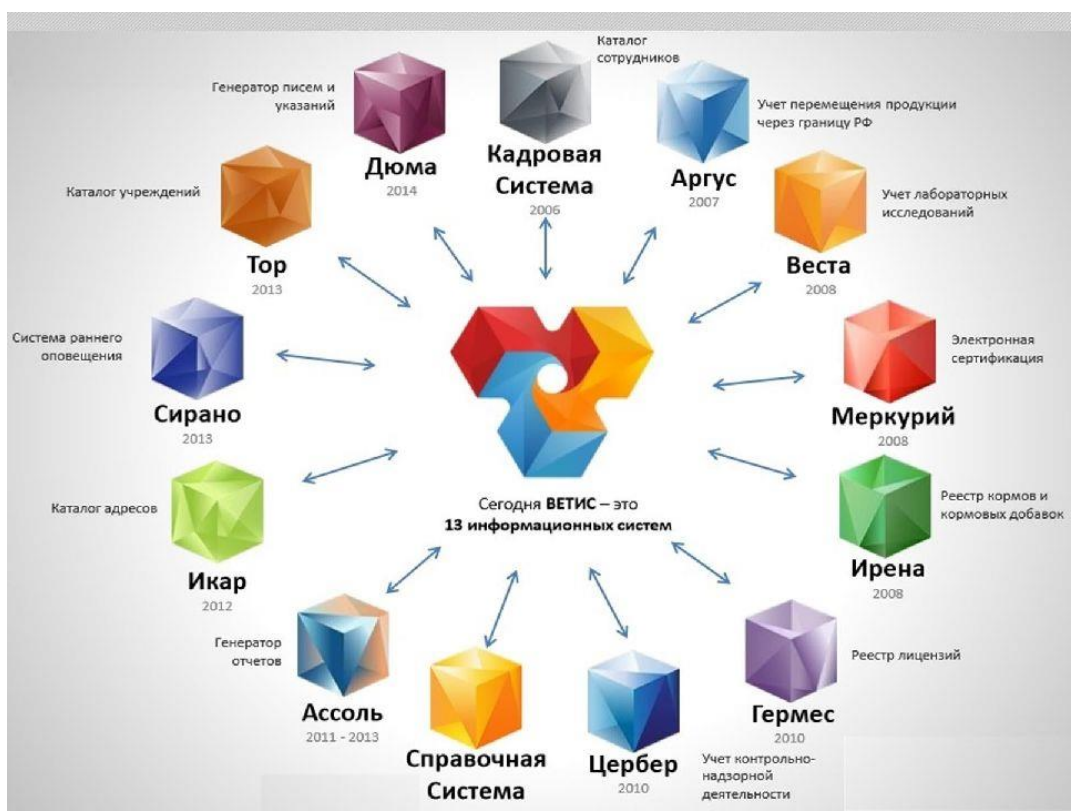

Рисунок 2. Информационные системы интегрированной системы ВетИС

В настоящее время существуют проблемы в следующих системах:

1. Меркурий - проблема корректной работы данной системы стоит наиболее остро, так как она прослеживает всю цепочку производства животноводческой продукции вплоть до поставки в магазины. Ввиду гигантского количества пользователей данная система часто дает сбои. Это приводит к задержке отправки товара от производителей в магазины, а также невозможности принятия партий товара ритейлерами ввиду их отсутствия в системе.

2. Аргус и Аргус Фито - ФГИС «АргусФито» - единый базы данных, предназначенные для оформления и проверки всех фитосанитарных/ветеринарных документов, сопровождающих продукцию на российский рынок. Если раньше подлинность документации приходилось заверять через посольства стран-экспортеров, то теперь необходимые данные собираются в электронную базу доступную для всех участников рынка. После присвоения уникального номера каждой партии можно отследить страну происхождения импортной продукции, вид транспорта и конечное место назначение.

Основные проблемы в работе данных систем связаны с человеческим фактором. Так, например, обновление базы данных может прекратиться из-за нерабочих дней в отдельных странах, откуда российские импортеры вывозят фрукты. Остановка внесения номеров сертификатов в единую базу оборачивается задержкой продукции на границе и потенциальными поте- рями для производителей.

Задача 7. Эффективное использование доведенных до Управления Россельхознадзора бюджетных средств.

Согласно ст. 34 Бюджетного Кодекса РФ [15] «принцип результативности и эффективности использования бюджетных средств означает, что при составлении и исполнении бюджетов участники бюджетного процесса в рамках установленных им бюджетных полномочий должны исходить из необходимости достижения заданных результатов с использованием наименьшего объема средств или достижения наилучшего результата с использованием определенного бюджетом объема средств».

Органы исполнительной власти до сих пор не имеют полного надежного набора показателей, пригодного для оценки непосредственных и конечных результатов, эффективности использования бюджетных средств [16].

Показатели оценки эффективности Управления, рассматриваемые в последующих главах субъективны. Например, с одной стороны, результатом контрольно-надзорной деятельности является выявление нарушений в полном объёме, то есть при качественном проведении проверки сумма выявленных нарушений должна быть как можно больше. С другой стороны, целью контрольно-надзорной деятельности Россельхознадзора является сокращение нарушений в подконтрольной сфере и улучшение обстановки в регионе. Данные индикаторы деятельности объединены в одном показателе, что 
говорит о его необъективности и невозможности отразить реальную ситуацию.

Более того, рассчитывать критерии эффективности необходимо исходя из достигнутого результата, который может быть отдален от периода выделения расходов на длительный временной лаг, что также необходимо учитывать при проведении контроля за эффективностью использования средств [17].
Разрабатывать критерии и показатели эффективности необходимо с учётом специфики отдельных сфер деятельности государства, причём достижение данных показателей не должно быть определяющим [18].

В результате анализа проблем реализации функций Управления Россельхознадзора определим основные направления решения проблем реализации функций (таблица 4).

\section{Таблица 4. Направления решения проблем реализации полномочий Управления Россельхознадзора}

\begin{tabular}{|c|c|}
\hline Проблемы & Направления решения \\
\hline $\begin{array}{l}\text { 1. Пересечение пол- } \\
\text { номочий контрольно- } \\
\text { надзорных органов }\end{array}$ & $\begin{array}{l}\text { Правовые: } \\
\text { - принятие административного регламента взаимодействия федеральных } \\
\text { органов государственной власти, осуществляющих государственный земельный } \\
\text { надзор, разграничивающего полномочия } \\
\text { Организационные: } \\
\text { - в рамках проведения ветеринарного надзора необходима централизация пол- } \\
\text { номочий на федеральном уровне }\end{array}$ \\
\hline $\begin{array}{l}\text { 2. Отсутствие регламен- } \\
\text { тации и стандартиза- } \\
\text { ции процессов осущест- } \\
\text { вления контрольных } \\
\text { мероприятий }\end{array}$ & $\begin{array}{l}\text { Правовые: } \\
\text { - правовое закрепление механизмов регулирования отношений в сфере произ- } \\
\text { водства и обращения зерна и продуктов его переработки; } \\
\text { - правовое закрепление алгоритма действий по снятию карантинных фитосани- } \\
\text { тарных зон с хозяйствующих субъектов } \\
\text { Методологические: } \\
\text { - разработка методов государственного регулирования в сфере производства и } \\
\text { обращения зерна и продуктов его переработки; } \\
\text { - разработка методов количественно-качественного учёта зерна и продуктов его } \\
\text { переработки в Российской Федерации }\end{array}$ \\
\hline $\begin{array}{l}\text { 3. Недостаточный } \\
\text { уровень регламентации } \\
\text { взаимодействия с орга- } \\
\text { нами прокуратуры }\end{array}$ & $\begin{array}{l}\text { Методологические: } \\
\text { - подготовка усовершенствованного соглашения о взаимодействии и сотрудниче- } \\
\text { стве с прокуратурой }\end{array}$ \\
\hline $\begin{array}{l}\text { 4. Несовершенство } \\
\text { контрольно-надзорных } \\
\text { процедур }\end{array}$ & $\begin{array}{l}\text { Правовые: } \\
\text { - внесение изменений в Земельный кодекс в рамках процедуры изъятия земель у } \\
\text { собственников } \\
\text { Методологические: } \\
\text { - разработка более эффективного алгоритма изъятия земель }\end{array}$ \\
\hline $\begin{array}{l}\text { 5. Недостаточный раз- } \\
\text { мер штрафов/налогов }\end{array}$ & $\begin{array}{l}\text { Правовые: } \\
\text { - внесение изменений в Кодекс об административных правонарушениях (по- } \\
\text { вышение размера штрафов за нарушение ст.8.8- «Использование земельных } \\
\text { участков не по целевому назначению» [19] и ст.10.12- «Нарушение правил произ- } \\
\text { водства, заготовки, обработки, хранения, реализации, транспортировки и исполь- } \\
\text { зования семян сельскохозяйственных растений») [14] } \\
\text { - внесение изменений в Налоговый кодекс (увеличение ставки по налогу за неис- } \\
\text { пользованные земельные участки) }\end{array}$ \\
\hline $\begin{array}{l}\text { 6. Отсутствие электрон- } \\
\text { ной фитосанитарной } \\
\text { сертификации }\end{array}$ & $\begin{array}{l}\text { Информационные: } \\
\text { - внедрение электронной фитосанитарной сертификации в автоматизированной } \\
\text { программе «Аргус Фито» } \\
\text { Правовые: } \\
\text { - закрепление в нормативно-правовых актах легитимности электронной фитоса- } \\
\text { нитарной сертификации }\end{array}$ \\
\hline $\begin{array}{l}\text { 7. Несовершенство име- } \\
\text { ющихся информацион- } \\
\text { ных систем Россельхоз- } \\
\text { надзора }\end{array}$ & $\begin{array}{l}\text { Информационные: } \\
\text { - увеличение производительности систем; } \\
\text { - развитие системы поддержки пользователей }\end{array}$ \\
\hline $\begin{array}{l}\text { 8. Неоднозначность } \\
\text { показателей эффектив- } \\
\text { ности использования } \\
\text { бюджетных средств }\end{array}$ & $\begin{array}{l}\text { Методологические: } \\
\text { - разработка критериев и показателей эффективности использования бюджет- } \\
\text { ных средств с учётом специфики контрольно-надзорной деятельности Управления } \\
\text { Россельхознадзора; } \\
\text { - достижение установленных показателей не должно быть определяющим, на их } \\
\text { основе не должны приниматься окончательные решения. }\end{array}$ \\
\hline
\end{tabular}


В сфере осуществления полномочий по контролю и надзору в соответствии с Решением Комиссии Таможенного союза от 18 июня 2010 г. № 317 «О применении ветеринарно-санитарных мер в Таможенном союзе» [20]; Решением Совета Евразийской экономической комиссии от 9 октября 2014 г. № 94 «О Положении о едином порядке проведения совместных проверок объектов и отбора проб товаров (продукции), подлежащих ветеринарному контролю (надзору)» [21]; Решением Комиссии Таможенного союза от 28 мая 2010 г. № 299 «О применении санитарных мер в Таможенном союзе» [22]; Техническим регламентом Таможенного союза «О безопасности пищевых продуктов» (ТР ТС 021/2011) [23]; Кодексом Российской Федерации об административных правонарушениях [24]; Федеральным законом от 12 апреля 2010 г. № 61-Ф3 «Об обращении лекарственных средств» [25]; Федеральным законом от 4 мая 2011 г. № 99-Ф3 «О лицензировании отдельных видов деятельности» [26]; Федеральным законом от 15 июля 2000 г. № 99Ф3 «О карантине растений» [12]; Решением Комиссии Таможенного союза от 09.12.2011 № 874 «O принятии технического регламента Таможенного союза «О безопасности зерна» [27]; Федеральным законом от 17 декабря 1997 г. № 149Ф3 «О семеноводстве» [28]; Земельным кодексом Российской Федерации [29].

Порядок ведения бюджетных смет регулируется приказом Минфина России от 20.11.2007 № 112н «Об общих требованиях к порядку составления, утверждения и ведения бюджетных смет казенных учреждений» [30] и приказом Россельхознадзора от 03.04.2018 г. № 293 «Об утверждении порядка составления, утверждения и ведения бюджетных смет центрального аппарата Россельхознадзора и территориальных органов Россельхознадзора» [31].

В качестве основных проблем реализации функций органа контрольно-надзорной деятельности были выделены следующие:

- пересечение полномочий контрольнонадзорных органов;

- отсутствие регламентации и стандартизации процессов осуществления контрольных мероприятий;

- недостаточный уровень регламентации взаимодействия с органами прокуратуры;

- несовершенство контрольно-надзорных процедур;

- недостаточный размер штрафов/налогов;

- отсутствие электронной фитосанитарной сертификации;

- несовершенство имеющихся информационных систем Россельхознадзора;

- неоднозначность показателей эффективности использования бюджетных средств.

В качестве путей решения указанных проблем выделены следующие основные направления:

- правовое: принятие административного регламента взаимодействия федеральных органов государственной власти; правовое закрепление механизмов регулирования отношений в сфере производства и обращения зерна и продуктов его переработки; закрепление в нормативно-правовых актах легитимности электронной фитосанитарной сертификации;

- методологическое: разработка методов государственного регулирования в сфере производства и обращения зерна и продуктов его переработки; разработка более эффективного алгоритма изъятия земель;

- информационное: внедрение электронной фитосанитарной сертификации в автоматизированной программе «Аргус Фито»; увеличение производительности систем; развитие системы поддержки пользователей.

\section{Библиографический список}

1. Федеральный закон “Об обороте земель сельскохозяйственного назначения” от 24.07.2002 N 101-Ф3 [Electronic resource]. URL: http://www.consultant.ru/document/cons_doc_LAW_37816/ (accessed: 20.11.2020).

2. Постановление Правительства РФ от 30 июня 2004 г. N 327 “Об утверждении Положения о Федеральной службе по ветеринарному и фитосанитарному надзору” (от 19 сентября 2020) [Electronic resource]. URL: https://base.garant.ru/12136097/ (accessed: 20.11.2020).

3. О Государственной программе развития сельского хозяйства и регулирования рынков сельскохозяйственной продукции, сырья и продовольствия (с изменениями на 3 октября 2020 года) [Electronic resource]. URL: http://docs.cntd.ru/document/902361843 (accessed: 20.11.2020). 
4. «Ведомственная целевая программа “Организация ветеринарного и фитосанитарного надзора” (утв. Россельхознадзором 30.11.2018) [Electronic resource]. URL: https://legalacts.ru/doc/vedomstvennaja-tselevajaprogramma-organizatsija-veterinarnogo-i-fitosanitarnogo-nadzora-utv/ (accessed: 20.11.2020).

5. ПРИКАЗ Россельхознадзора от 09.10.2015 n 686 (ред. от 25.09.2020) “об утверждении нормативных затрат на обеспечение функций территориальных управлений Россельхознадзора” [Electronic resource]. URL: https:// gkrfkod.ru/zakonodatelstvo/prikaz-rosselkhoznadzora-ot-09102015-n-686/ (accessed: 20.11.2020).

6. ПРИКАЗ от 25 января 2017 г. N 51 «Об осуществлении полномочий заказчика федеральной службой по ветеринарному и фитосанитарному надзору, ее территориальными управлениями и учреждениями, в отношении которых Россельхознадзор осуществляет функции и полномочия [Electronic resource]. URL: https:// rulaws.ru/acts/Prikaz-Rosselhoznadzora-ot-25.01.2017-N-51/ (accessed: 20.11.2020).

7. Родионов Д.Г. Опыт государственного и общественного регулирования сферы услуг в странах запада // Вестник образования и развития науки Российской академии естественных наук. 2004. № 8. Р. 53.

8. Постановление Правительства РФ от 2 января 2015 г. N 1 “Об утверждении Положения о государственном земельном надзоре” (от 7 сентября 2020г) [Electronic resource]. URL: https://base.garant.ru/70836144/ (accessed: 20.11.2020).

9. Родионов Д. Г. Стратегия повышения эффективности функционирования инновационного предприятия // Российский экономический интернет-журнал2. 2018. Vol. 4. P. 94.

10. Постановление Правительства РФ от 5 июня 2013 г. N 476 “О вопросах государственного контроля (надзора) и признании утратившими силу некоторых актов Правительства Российской Федерации” (от 23 сентября 2020).

11. Приказ Россельхознадзора от 28.03.2011 г. № 98 «Об утверждении Кодекса этики и служебного поведения государственных служащих Россельхознадзора» [Electronic resource]. URL: https://legalacts.ru/doc/prikazrosselkhoznadzora-ot-28032011-n-98-ob/ (accessed: 20.11.2020).

12. Федеральный закон “О карантине растений” от 21.07.2014 N 206-Ф3 [Electronic resource]. URL: http://www. consultant.ru/document/cons_doc_LAW_165795/(accessed: 20.11.2020).

13. Приказ Минсельхоза РФ от 13.02.2008 N 43 Об установлении и упразднении карантинной фитосанитарной зоны, установлении и отмене карантинного фитосанитарного режима, о наложении и снятии карантина [Electronic resource]. URL: https://legalacts.ru/doc/prikaz-minselkhoza-rf-ot-13022008-n-43/ (accessed: 20.11.2020).

14. “Кодекс Российской Федерации об административных правонарушениях” от 30.12.2001 N 195-Ф3 (ред. от 15.10.2020, с изм. от 16.10.2020) [Electronic resource]: Статья 10.12. URL: http://www.consultant.ru/document/ cons_doc_LAW_34661/c3c2eaa1f332f66b99054b4a87c6e4248306a7c5/ (accessed: 20.11.2020).

15. “Бюджетный кодекс Российской Федерации” от 31.07.1998 N 145-Ф3 (ред. от 15.10.2020) [Electronic resource]: Статья 34. URL: http://www.consultant.ru/document/cons_doc_LAW_19702/9d0dc5bffbe52f6f95e97813e0ef4207 08952b4e/ (accessed: 20.11.2020).

16. Родионов Д.Г. К теоретической оценке государственного и негосударственного регулирования рыночной экономики // Проблемы современной экономики. 2003. № 3-4. Р. 55-57.

17. Приказ Россельхознадзора от 14 сентября 2016 г. № 663 «О Регламенте Федеральной службы по ветеринарному и фитосанитарному надзору» [Electronic resource]. URL: https://rulaws.ru/acts/Prikaz-Rosselhoznadzoraot-14.09.2016-N-663/ (accessed: 20.11.2020).

18. Жиляева И.А., Родионов Д.Г. Проблемы и механизмы адаптивного управления сферой услуг массового потребления в городах Российской Федерации // Экономика и предпринимательство. 2016. № 10-1. Р. 163167.

19. “Кодекс Российской Федерации об административных правонарушениях” от 30.12.2001 N 195-Ф3 (ред. от 15.10.2020, с изм. от 16.10.2020) [Electronic resource]: Статья 8.8. URL: http:/www.consultant.ru/document/ cons_doc_LAW_34661/d4131daeffceff28e2dda2eba7105f88abc9e7e9/ (accessed: 20.11.2020).

20. Решение КТС от 18.06.2010 № 317 “О применении ветеринарно-санитарных мер в Евразийском экономическом союзе” [Electronic resource]. URL: https://www.alta.ru/tamdoc/10sr0317/ (accessed: 20.11.2020).

21. Решение Совета Евразийской экономической комиссии от 9 октября 2014 г. N 94 “О Положении о едином порядке проведения совместных проверок объектов и отбора проб товаров (продукции), подлежащих ветеринарному контролю (надзору)” [Electronic resource]. URL: https://www.alta.ru/tamdoc/14sr0094/ (accessed: 20.11.2020).

22. Решение Комиссии Таможенного союза от 28 мая 2010 г. N 299 “О применении санитарных мер в Евразийском экономическом союзе” [Electronic resource]. URL: https:/www.alta.ru/tamdoc/10sr0299/ (accessed: 20.11.2020). 
23. Технический регламент Таможенного союза о безопасности пищевой продукции (тр тс 0212011 ) [Electronic resource]. URL: https://gosnorm.ru/oblast-akkreditacii/55-tr-ts-021-2011-tehnicheskiy-reglamenttamozhennogo-soyuza-o-bezopasnosti-pischevoy-produkcii.html (accessed: 20.11.2020).

24. “Кодекс Российской Федерации об административных правонарушениях” от 30.12.2001 N 195-Ф3 (ред. от 15.10.2020, с изм. от 16.10.2020) [Electronic resource]. URL: http://www.consultant.ru/document/cons_doc_ LAW_34661/ (accessed: 20.11.2020).

25. Федеральный закон “Об обращении лекарственных средств” от 12.04.2010 N 61-Ф3 (последняя редакция) [Electronic resource]. URL: http://www.consultant.ru/document/cons_doc_LAW_99350/ (accessed: 20.11.2020).

26. Федеральный закон “О лицензировании отдельных видов деятельности” от 04.05.2011 N 99-ФЗ (последняя редакция) [Electronic resource]. URL: http://www.consultant.ru/document/cons_doc_LAW_113658/ (accessed: 20.11.2020).

27. Решение Комиссии Таможенного союза Евразийского экономического сообщества от 9 декабря 2011 г. N 874 “О принятии технического регламента Таможенного союза 'О безопасности зерна” [Electronic resource]. URL: https://www.alta.ru/tamdoc/11sr0874/ (accessed: 20.11.2020).

28. Федеральный закон от 17 декабря 1997 г. N 149-ФЗ “О семеноводстве” (с изменениями и дополнениями) [Electronic resource]. URL: https://base.garant.ru/12106441/ (accessed: 20.11.2020).

29. “Земельный кодекс Российской Федерации” от 25.10.2001 N 136-Ф3 (ред. от 15.10.2020) [Electronic resource]. URL: http://www.consultant.ru/document/cons_doc_LAW_33773/ (accessed: 20.11.2020).

30. Приказ Минфина РФ от 20 ноября 2007 г. N 112н “Об общих требованиях к порядку составления, утверждения и ведения бюджетных смет казенных учреждений” (от 23 марта 2018 г.) [Electronic resource]. URL: https://base.garant.ru/12157835/ (accessed: 20.11.2020).

31. ПРИКАЗ от 3 апреля 2018 г. N 293 Об утверждении порядка составления, утверждения и ведения бюджетных смет центрального аппарата Россельхознадзора и территориальных органов Россельхознадзора. [Electronic resource]. URL: https://rulaws.ru/acts/Prikaz-Rosselhoznadzora-ot-03.04.2018-N-293/ (accessed: 20.11.2020). 